\title{
COVID-19: Novel Opinion on Strategic Prophylaxis and Cure Using Vitamin C (Ascorbic Acid)
}

\author{
Ohanube Goodluck Anthony $\mathrm{K}^{\mathbf{1}}$ and Obeta Mark Uchejeso ${ }^{2 *}$ \\ ${ }^{1}$ Institute of Neurophysiology, Cologne, Germany, \\ ${ }^{2}$ Federal School of Medical Laboratory Science, Jos, Nigeria \\ *Corresponding Author: Obeta Mark Uchejeso, Federal School of Medical \\ Laboratory Science, Jos, Nigeria.
}

\author{
Received: March 29, 2020 \\ Published: April 28, 2020
}

(C) All rights are reserved by Ohanube Good-

luck Anthony K and Obeta Mark Uchejeso.

\begin{abstract}
The number of COVID-19 infection across the globe and in Nigeria in particular is on the rapid rise without commensurate treatment and cure. The search for cure and eradication of the pandemic is on the increase. Vitamin C has been postulated by this paper as one of the treatment measures that can reduce infection rate and also contribute to the cure of COVID-19. The paper calls for healthcare givers across the globe to also cue in towards better management of COVID-19 through the use of intravenous infusion at doses 1000 - $2000 \mathrm{mg}$ for adults, 500 - $1000 \mathrm{mg}$ for children for 5 to 7 days and tapered; or tablets 1000 - $2000 \mathrm{mg}$ for adults and 500 - $1000 \mathrm{mg}$ for children for 7 to 14 days and tapered for curative treatments and tablets $500-1000 \mathrm{mg}$ for adults and $200-500$ $\mathrm{mg}$ for kids for 3 month for prophylaxis.
\end{abstract}

Keywords: COVID-19; Vitamins C; Infusion; Prophylaxis; Cure

\section{Introduction}

Coronavirus is an emerging and re-emerging infectious virus that have been known for a long time. The reemergence in 2019 has challenged the global health, politics and economics. The management and treatment remains global challenge that calls for various medical and scientific approach for cure and total eradication. This paper gives an opinion towards the use of Vitamin C for prophylaxis and cure.

\section{Coronavirus (COVID-19)}

Coronavirus is as old as virus itself which was noted in 1918 in human, 1930's in animals and recorded in humans again in the 1960's, then in 2003. COVID-19 is an emerging infectious diseases earlier called novel coronavirus disease that was traced to China since 8 December 2019 [1], with symptoms such as: feeling short of breath, having a cough that gets more severe over time, and a low-grade fever that gradually increases in temperature. The new virus that causes COVID-19 is severe acute respiratory syndrome coronavirus 2 (SARS-COV-2) as named by WHO [2]. The virus can lead to pneumonia, respiratory failure, septic shock, and death. Early symptoms of the disease are: fever, dry cough, fatigue while severe symptoms includes: trouble breathing or shortness of breath, ongoing chest pain or pressure, new confusion, difficulty to wake up and bluish lips or face [3].

\section{Vitamin C (Ascorbic acid)}

Vitamin C also called ascorbic acid is a vitamin found particularly in citrus fruits (fruits) and vegetables and has capacity to maintain healthy connective tissues. The sources of ascorbic acid includes: Indian gooseberry, citrus fruits such as limes, oranges and lemons, tomatoes, potatoes, papaya, green and red peppers, kiwifruit, strawberries berries, cauliflower, Brussels sprouts, cabbage, and spinach, and cantaloupes, green leafy vegetables such as broccoli, fortified cereals and its juices. Vitamin C (Ascorbic acid) is an antioxidant of which the deficiency has been named scurvy which is one of the symptoms of pneumonia. Vitamin C may have been shown by several studies to alleviate or prevent infections caused by bacteria, viruses, and protozoa [4-6] and also improve the mood of acutely hospitalized patients [7]. Pneumonia has been implicated in oxidative stress in lungs [8]. More importantly, intravenous vitamin $\mathrm{C}$ has been employed as an adjunctive interventional agent in the therapy of recurrent acute respiratory distress syndrome (ARDS) [9].

\section{Treatment of COVID-19}

COVID-19 currently do not have a confirmed treatment though management is ongoing with various clinical trials with hope of vaccine as soon as possible. Many have been treatment and reported negative in various countries. Various trials made so far includes: Japan flu drugs, antiviral drug - Favipiravir or Avigan, Chloroquine and hydroxychloroquine, failed Ebola drug - remdesivir, HIV drug combination- combination of lopinavir and ritonavir, An immunosuppressant and an arthritis drug - Actemra, or tocilizumab with interleukin 6 (IL-6) i.e. cytokine, sarilumab or tocilizumab, blood pressure drug- Losartan, and possible use of large dose of Vitamin C [10-12]. Though, Zhi [12], started a clinical trial in Zhongnan Hos- 
pital, China from $11^{\text {th }}$ February, 2020, with some countries looking the other way in the issue of Vitamin C infusion [13], our idea is original and practically working with use of Vitamin $\mathrm{C}$ for the treatment of COVID-19 as we present our work soon to various health authorities on the prophylactic and curative use of Vitamin C.

\section{Vitamin C (Ascorbic acid); a novel treatment}

With our case study in Bonn, Germany, we are convinced that vitamin C (Ascorbic acid) tablet works on the COVID-19 patients and care givers. Ascorbic acid has a pH of $1-2.5$ and COVID-19 has an optimal activity in pH 6 - 7.5. At a steady state, intravenous (I.V) Ascorbic acid has the capacity to acidify the environment of the respiratory tract; attenuating the virulence and infectivity of the viral agent of COVID-19. After which it kills this virus and enhances the alveolar immunity. This it does by temporarily and slightly changing the $\mathrm{pH}$ of the respiratory tract.

The virus, SARS-COV-2 has a peculiar way of gradually building up its viral load which overwhelms the already fortified immune system of medical doctors, nurses and medical laboratory scientists who were involved. This explains the death of some doctors and nurses within few weeks of work. This situation often happens via droplets and aerosols expelled by patients. Hence, we suggest a strategy of weekly, gradual upward review of the vitamin C dose; a monthly COVID-19/CD-4 count; and change of care if CD4 count becomes too high. Also, treating COVID-19 in most cases has a possibility of boosting immunity against Hanta virus.

Thus, for treatment, we suggest Vitamin C (Ascorbic acid) intravenous infusion (IV) $1000-2000 \mathrm{mg}$ is to be given to adults for 5 to 7 days and tapered. For kids, $500-1000 \mathrm{mg}$ for 5 to 7 days and tapered. This is to achieve a steady state.

Vitamin C (Ascorbic acid) tablets is to be given to adults for 7 to 14 days and tapered. For kids, $500-1000 \mathrm{mg}$ for 7 to 14 days and tapered. This is to achieve a steady state.

For prophylaxis, we suggest a $500-1000 \mathrm{mg}$ of Vitamin C (Ascorbic acid) tablets for adults and 200 - $500 \mathrm{mg}$ for kids for at least 3 month for at least 3 month

The recommendations should be taken with plenty of water and 8 or more hours of sleep daily.

\section{Conclusion}

The use of Vitamin C (ascorbic acid) may be under rated but this paper suggests that the hypothesis we have proffered based on this article is to opine that Vitamin $\mathrm{C}$ at a steady state is efficient in preventing and managing COVID-19. It is always important to remember the guidelines of the WHO and local health authorities in the management and healthcare of COVID-19 patients while using other treatment measures such as the use of Vitamin C (ascorbic acid) in the treatment of COVID-19.

\section{Bibliography}

1. Novel C.P.E.R.E. "The epidemiological characteristics of an outbreak of 2019 novel coronavirus diseases (COVID-19) in China". Zhonghua Liu Xing Bing Xue Zazhi= Zhonghua Liuxingbingxue Zazhi 41.2 (2020): 145.

2. World Health Organization. "Pneumonia of unknown cause - China" (2020).

3. Nassiri N. "Perspective on Wuhan Viral Pneumonia". Advances in Public Health, Community and Tropical Medicine (2020): APCTM-106.

4. Harri Hemilä. "Vitamin C and Infections". Nutrients 9.4 (2017): E339.

5. Markos G Kashiouris., et al. "The Emerging Role of Vitamin C as a Treatment for Sepsis". Nutrients 12.2 (2020): E292.

6. May JM and Harrison FE. "Role of vitamin C in the function of the vascular endothelium". Antioxidants and Redox Signaling 19.17 (2013): 2068-2083.

7. Zhang M., et al. "Vitamin C provision improves mood in acutely hospitalized patients". Nutrition 27.5 (2011): 530-533.

8. Duflo F., et al. "Alveolar and serum oxidative stress in ventilator-associated pneumonia". British Journal of Anaesthesia 89.2 (2002): 231-236.

9. Amit Bharara., et al. "Intravenous Vitamin C Administered as Adjunctive Therapy for Recurrent Acute Respiratory Distress Syndrome". Case Reports in Critical Care (2016): 8560871.

10. Livescience. "Treatments for COVID-19: Drugs being tested against the coronavirus" (2020).

11. Wang M., et al. "Remdesivir and chloroquine effectively inhibit the recently emerged novel coronavirus (2019-nCoV) in vitro". Cell Research 30.3 (2020): 269-271.

12. Zhi Yong Peng. Vitamin C Infusion for the Treatment of Severe 2019-nCoV Infected Pneumonia" (2020).

13. DoH Australia. "No evidence to support intravenous high-dose vitamin C in the management of COVID-19". Alert/Advisory, Medicines safety (2020).

\section{Assets from publication with us}

- Prompt Acknowledgement after receiving the article

- Thorough Double blinded peer review

- Rapid Publication

- Issue of Publication Certificate

- High visibility of your Published work

Website: https://www.actascientific.com/

Submit Article: https://www.actascientific.com/submission.php

Email us: editor@actascientific.com

Contact us: +919182824667 